\title{
INVESTIGATION OF DRYING KINETICS OF APRICOTS IN DIFFERENT ENVIRONMENTS
}

\author{
Kayısıların Farklı Ortamlarda Kurutma Kinetiğinin İncelenmesi \\ Mehmet Alper ASLAN ${ }^{1}$ (i) Yunus ÖNAL ${ }^{2}$ (1) \\ Yeliz AKBULUT ${ }^{3}$ Canan AKMIL BASSAR ${ }^{4}$ (1) \\ ${ }^{1,2,3,4}$ Department of Chemical Engineering, Inonu University, Malatya, Turkey
}

\begin{tabular}{ll}
\hline Geliş Tarihi / Received: 02.12.2020 & Kabul Tarihi / Accepted: 06.02.2021 \\
\hline
\end{tabular}

\begin{abstract}
In this study, Çöloğlu, Hacıhaliloğlu, Kabaaşı and Karacabey apricot species grown in Malatya province of Turkey were used. The effects of various drying environment on the drying kinetics of crude and pre-treated apricots have been investigated. The experiments were conducted in the sunlight and in the shade environment with SO2 treated and untreated apricot. While the drying speed curves of the dried apricots increased rapidly at the beginning, the drying speed curve started to decrease afterwards. The data was fitted to five different mathematical models. Midilli et al. model was determined as the best one to explain drying of apricots by comparing the coefficient of correlation determination (R2), mean absolute percentage error (MAPE) and root mean square error (RMSE) between the observed and expected moisture ratios.
\end{abstract}

Keywords: Apricot, Drying, Mathematical modelling, Moisture diffusion.

\section{ÖZ}

Bu çalışmada Türkiye'nin Malatya ilinde yetişen Çöloğlu, Hacıhaliloğlu, Kabaaşı ve Karacabey kayısı türleri kullanıldı. Çeşitli kurutma ortamlarının ham ve önceden işlenmiş kayısıların kurutma kinetiği üzerindeki etkileri araştırılmıştır. Deneyler güneş ışığında ve gölge ortamında SO2 ile muamele edilmiş ve işlenmemiş kayısı ile gerçekleştirildi. Kuru kayısıların kurutma hızı eğrileri başlangıçta hızla artarken, kurutma hızı eğrisi daha sonra azalmaya başladı. Veriler beş farklı matematiksel modele uyarlandı. Midilli ve ark. modeli, gözlemlenen ve beklenen nem oranları arasındaki; korelasyon katsayısı (R2), ortalama mutlak yüzde hata (MAPE) ve kök ortalama kare hata (RMSE) karşılaştırılarak kayısıların kurutulmasını açıklamak için en iyi model olarak belirlendi.

Anahtar kelimeler: Kayısı, Kurutma, Matematiksel modelleme, Nem difüzyonu. 


\section{INTRODUCTION}

Drying is the process of heat and mass transfer, in which the water in the structure of fruits and vegetables is minimized (Akpınar Kavak, Biçer, \& Midilli, 2003). Drying process is one of the best ways to preserve fruits like apricot. Apricot (Prunus armenical), with high respiration and short ripening time, is not a climacteric fruit. Dried apricot reduces the damages, weight and volume losses, packaging space, storage and handling costs. Compared to dry apricots and fresh apricots, it has advantages such as less damage, no weight and volume losses, and reduced packaging, storage and transportation costs. All leading apricot producers like Turkey, Iran and Australia apply the drying process on their apricot fruit (Akpınar Kavak, Biçer, \& Yildiz, 2003). Drying involves heat and mass transfer events that are difficult to mathematically define. According to the drying method applied, heat transfer occurs by conduction, convection and radiation. In the case of food drying, the drying constant is used instead of the transport properties. The drying constant has the unifying effect of all transport properties (Bozkır, 2006). Anisotropic and heterogeneous structure of agricultural products, and irregular shapes due to changes in shape during drying, thin layer drying of agricultural products consists of data about most of the studies, and mainly empirical in nature. Due to the anisotropic, heterogeneous structure and irregular shapes of agricultural products and shape changes during drying, this makes it mandatory to dry agricultural products in a thin layer. Therefore, most such studies consist mainly of data of an empirical nature. (Diamante \& Munro, 1991; Glen, 1949). In drying technologies; modeling of drying kinetics, desiccant design and optimization, process control, dehumidification mechanism are very important. There have been numerous experimental studies involving modeling on monolayer drying in the literature (Krokida, Karathanos, Maroulis, \& Marinos-Kouris, 2003; Sarsavadiya, Sawhney, Pangavhane, \& Singh, 1999).

Apricot species specific to Malatya province (Hacıhaliloğlu, Kabaaşı, Çöloğlu and Karacabey) are quite different from other apricot species in terms of total solid matter and content. Much of the production is done in the world and in Turkey, Malatya. In addition, it is of great importance that $90 \%$ of the production is export product. For this reason, sulfurization and drying of apricots is of great importance.

The aim of this study is to investigated the drying process of four different types fruits in the different environments ( 30 and $50^{\circ} \mathrm{C}$ ) incubator, shade, daylight with selected a single layer drying models by using appropriate statistical analysis procedures to examine the applicability of the most suitable model. The aim of this study is to perform single-layer drying in different environments (30 and $50^{\circ} \mathrm{C}$ ) such as incubator, shade, daylight using four different 
fruit varieties and to determine the most suitable drying model for this drying process using appropriate statistical analysis procedures.

\section{MATERIAL AND METHOD}

\section{Sample Preparation, Drying}

Çöloğlu, Hacıhaliloğlu, Kabaaşı and Karacabey apricot species which have been used in our studies were obtained from Malatya Apricot Research Institute. While some of them were sulfurized, some of them were used without being subjected to sulfurization process. The color of the apricot varies greatly during drying. The apricot can be dried after it has been sulfurized in order to; protect the natural color of it, prevent damage caused by microorganisms during storage and store for a longer time. The fresh apricot has been sulfurized by keeping in the $\mathrm{SO}_{2}$ atmosphere formed by burning elemental sulphide in a specially made, close system (the sulphur room) for this purpose. The apricots were laid in a single row on a poplar wood tray and then were taken to the sulfur room. Sulfurization was carried out by keeping the apricots in the atmosphere of $\mathrm{SO}_{2}$ gas formed by burning about 1.5-2 g sulphur per kilogram of apricots.

Prepared apricots are dried in the sun and shade at intervals of $0.5 \mathrm{~cm}$ in the size of $60 * 60$ $\mathrm{cm}$ on specially designed wooden trays. Drying in the shade is carried out for products which can lose their color and/or turn brown if put in direct sunlight. When natural, bright fruits such as apricots are dried in the shade, the sugar in the structure does not caramelize, so the color in the product remains light brownly. Apricots, which are dried, are fully dried in an environment with air circulation. Therefore, the drying process is done in the shade. Drying in the shade takes longer than drying in the sun. But if the drying is in the dry area and in the environment with air circulation, the time is slightly shorter.

The prepared apricot samples were placed on wooden crayfish consisting of $0.5 \mathrm{~cm}$ spaced gaps in dimensions of $60 * 60 \mathrm{~cm}$, which were specially manufactured before the experiment, and dried in the sun. Drying in the shade is carried out for products that can lose their color and/or turn brown if put in direct sunlight. When natural, bright fruits such as apricots are dried in the shade, the sugar in the structure does not caramelize, so the color in the product remains light brown. Then apricots, which are dried, are fully dried in an environment with air circulation. Therefore, the drying process is done in the shade. Drying in the shade takes longer than drying in the sun. But if the drying is in the dry area and in the environment with air circulation, the time is slightly shorter.

The nuclei of the partially dried apricots were removed one by one by hand and the shaped apricots were continuously dried until a fixed weighing was obtained. The temperature of the 
sun dried apricots during the day was $30-50^{\circ} \mathrm{C}$; and the temperature of the dried apricots in the shade was $20-30^{\circ} \mathrm{C}$.

Moisture content based on dry weight $\left(\mathrm{M}_{\mathrm{c}}\right)$ was calculated by using equation (1):

$M c=\frac{m_{1}-m_{2}}{m_{2}} \times 100$

where, $\mathrm{m}_{1}$ is the initial mass of samples $(\mathrm{g})$ and $\mathrm{m}_{2}$ is the mass of samples after drying ( $\mathrm{g}$ ).

Drying rate is defined by the loss of moisture from the wet solid per each unit of time, and analytically drying rate (R) refers to the unit area of surface drying according to the equation:

$$
R=\frac{S}{A}\left(-\frac{d M}{d t}\right)
$$

where, $\mathrm{S}$ is the weight of a dry solid, $\mathrm{A}$ is the surface area exposed and $-\frac{d M}{d t}$ is the change of humidity with regard to time.

\section{Mathematical Modeling}

The data on moisture ratio were used for modeling of drying apricot. Based on equation (3), the moisture ratio (MR), depends on the initial moisture $\left(M_{0}\right)$, equilibrium moisture $\left(M_{e}\right)$ and the moment moisture on the dry basis (M).

$M R=\frac{M-M_{e}}{M_{0}-M_{e}}$

However, this could be simplified to Eq. 4, because the relative humidity of the drying air fluctuated continuously under open-air drying conditions (Sawhney, Pangavhane, \& Singh, 1999; Sharaf-Eldeen, Hamdy, Keener, \& Blaisdell, 1979).

$M R=\frac{M_{t}}{M_{0}}$

For mathematical modeling, five widely used mathematical models have been applied to select the best model for describing the drying curve equation of apricot during the drying process. These models are summarized in Table 1.

Table 1. Mathematical Models Used to Describe the Drying Behavior of Apricot 


\begin{tabular}{|c|c|c|c|}
\hline $\begin{array}{l}\text { Model } \\
\text { no }\end{array}$ & Model name & ation & Reference \\
\hline 1 & Page & $M R=\exp \left(-k t^{t}\right)$ & $\begin{array}{l}\text { (Pala, } \\
\text { Mahmutoglu, \& } \\
\text { Saygi, 1996) }\end{array}$ \\
\hline 2 & Newton & $M R=\exp (-k t)$ & $\begin{array}{l}\text { (O’Callaghan, } \\
\text { Menzies, \& } \\
\text { Bailey, 1971) }\end{array}$ \\
\hline 3 & $\begin{array}{l}\text { Modified Handerson and } \\
\text { Pabis }\end{array}$ & $\begin{aligned} M R=\operatorname{aexp}(-k t) & +b \exp (-g t) \\
& +c \exp (-h t)\end{aligned}$ & $\begin{array}{l}\text { (Sharma, Verma, } \\
\text { \& Pathare, } \\
\text { 2005) }\end{array}$ \\
\hline 4 & Approximation of diffusion & $M R=\operatorname{aexp}(-k t)+(1-a) \exp (-k b t)$ & $\begin{array}{l}\text { (Sharaf-Eldeen et } \\
\text { al., 1979) }\end{array}$ \\
\hline 5 & Midilli et al. & $M R=\operatorname{aexp}\left(-k t^{n}\right)+b t$ & $\begin{array}{l}\text { (Midilli, Kücük, } \\
\text { \& Yapar, 2002) }\end{array}$ \\
\hline
\end{tabular}

Sequential Quadratic Programming (SQP) method, which is an effective optimization method, has been used to determine the model parameters. The correlation coefficient $\left(\mathrm{R}^{2}\right)$ was one of the criteria for selecting the best equation to describe the drying curve equation. Furthermore, the mean absolute percentage error (MAPE) for the models and root mean square error analysis (RMSE) was used to determine the goodness of fit. The higher values of the $\mathrm{R}^{2}$ and the lower values of MAPE and RMSE lead to the better goodness of fit (Sharma et al., 2005; Toğrul-Türk \& Toğrul, 2007; Yaldiz \& Ertekin, 2001). These can be calculated as following:

$R^{2}=\frac{\sum_{i=1}^{n}\left(M R_{i}-M R_{\text {pre }, i}\right) \sum_{i=1}^{n}\left(M R_{i}-M R_{\text {exp }, i}\right)}{\sqrt{\left[\sum_{i=1}^{n}\left(M R_{i}-M R_{\text {pre }, i}\right)^{2}\right]\left[\sum_{i=1}^{n}\left(M R_{i}-M R_{\text {exp }, i}\right)^{2}\right]}}$

MAPE $=\frac{100}{\mathrm{~N}}\left[\sum_{\mathrm{i}=1}^{\mathrm{N}} \frac{\left|M R_{\text {exp }, i}-M R_{\text {pre }, i}\right|}{M R_{\text {pre }, i}}\right]$

$R M S E=\left[\frac{1}{N} \sum_{i=1}^{N}\left(M R_{p r e, i}-M R_{\exp , i}\right)^{2}\right]^{\frac{1}{2}}$

where $M R_{\text {exp,i }}$ is the $i$ th experimentally observed moisture ratio, $M_{\mathrm{pre}, \mathrm{i}}$ is the $i$ th expected moisture ratio, $N$ is the number of observations and $n$ the number of constants.

\section{DISCUSSION}

The change in moisture content over time as a result of apricot drying in the sun and shade environment for untreated and sulphur treated Çöloğlu, Hacıhaliloğlu, Kabaaşı and Karacabey species is given in Fig 1-4. 

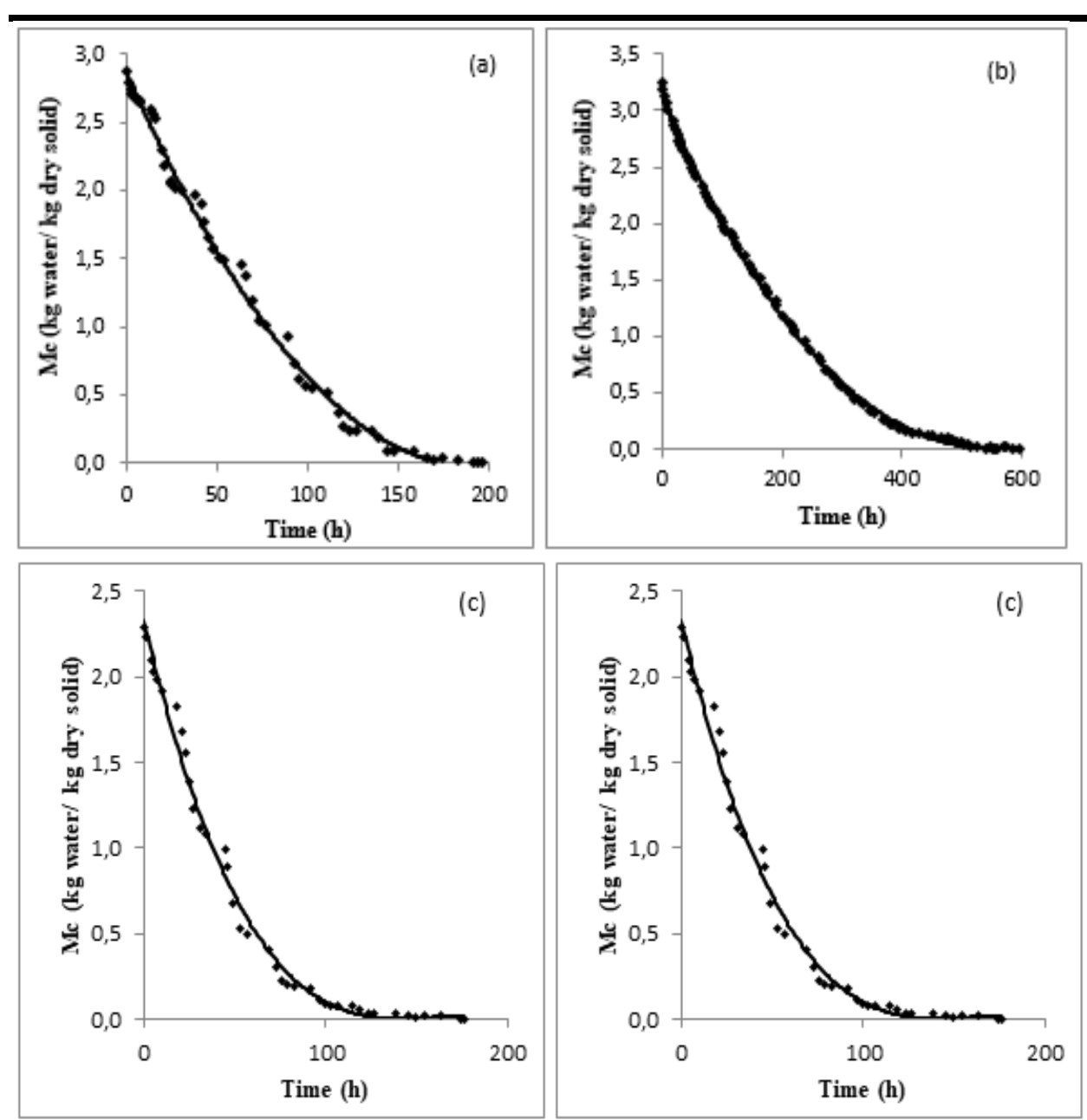

Figure 1. Moisture Content Change Over Time During Drying of Untreated Çöloğlu Apricot Species in the (a) Sunlight and (b) Shade and Sulphur Treated in the (c) Sunlight and (d) Shade

When Figure 1-4 is examined, for untreated species, it is seen that the dryness is completed at about 175 hours except the Karacabey apricot, but it is completed at the 80th hour in the sunlight. 


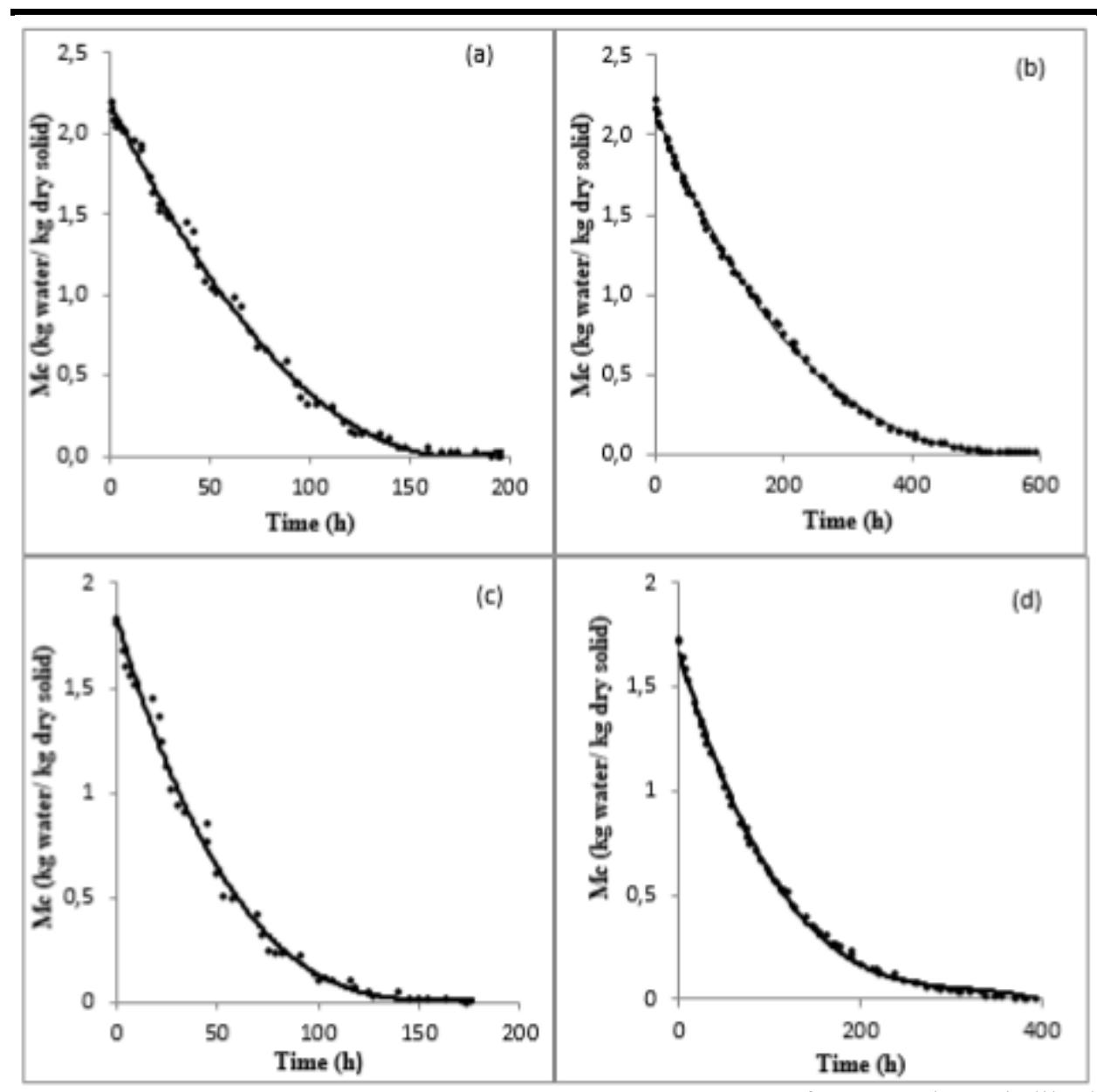

Figure 2. Moisture Content Change Over Time During Drying of Untreated Hacıhaliloğlu Apricot Species in the (a) Sunlight and (b) Shade and Sulphur Treated in the (c) Sunlight and (d) Shade 


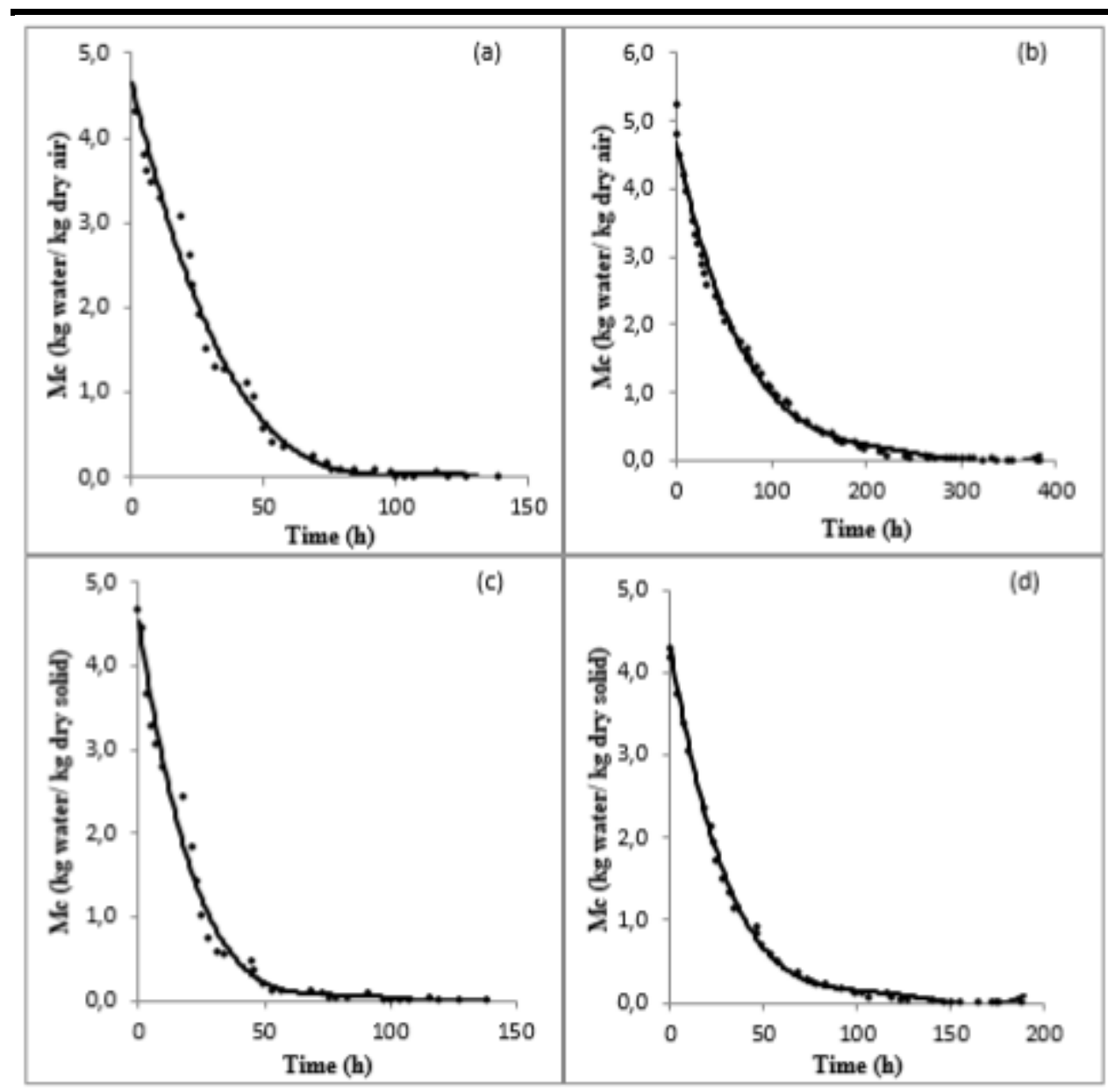

Figure 3. Moisture Content Change Over Time During Drying of Untreated Karacabey Apricot Species in the (a) Sunlight and (b) Shade and Sulphur Treated in the (c) Sunlight and (d) Shade

It is observed that drying in the shade is completed for 500 hours for the same species and 300 hours for Karacabey species. Apricots of the same type are completely dried within 500 hours, while Karacabey types have been found that drying is completed within 300 hours under shade conditions. Since the species of Karacabey is an early maturing species, its biological texture is different from the others. 


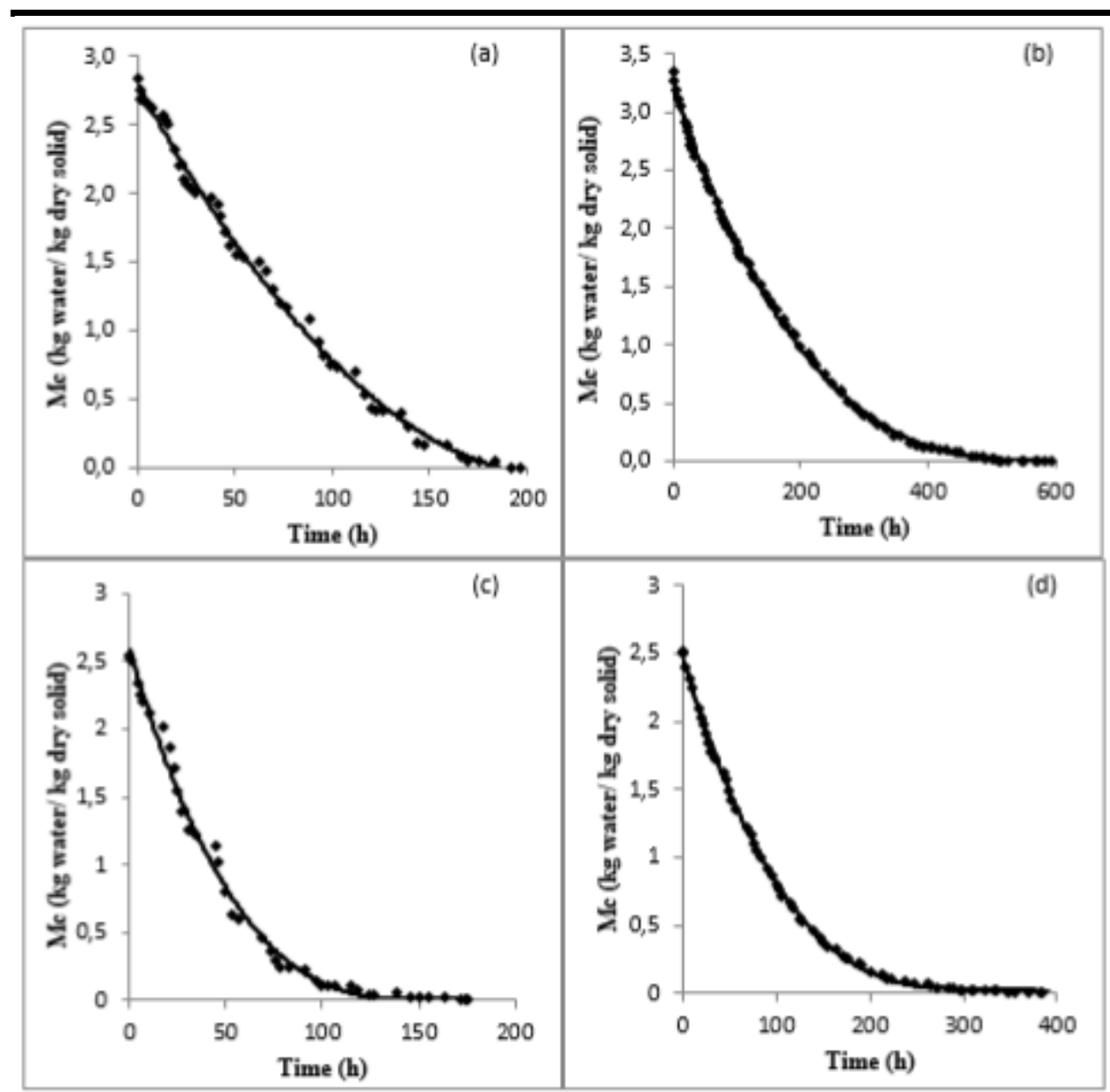

Figure 4. Moisture Content Change Over Time During Drying of Untreated Kabaaşı Apricot Species in the (a) Sunlight and (b) Shade and Sulphur Treated in the (c) Sunlight and (d) Shade

In addition, Karacabey's drying surface area is higher, so the moisture content decreases faster. When the change in moisture content is examined in the drying process of sulfur-treated apricots, these apricots appear to dry earlier than untreated apricots in both sun and shade environments. The reason for this situation is the swelling of the outer tissue of the apricot and opening of the pores after sulphur treatment.

The drying rate of the apricot is calculated by the Eq. 4 for drying of untreated and sulphur treated species. The change in drying rate over moisture content is given in Fig. 5-8. 


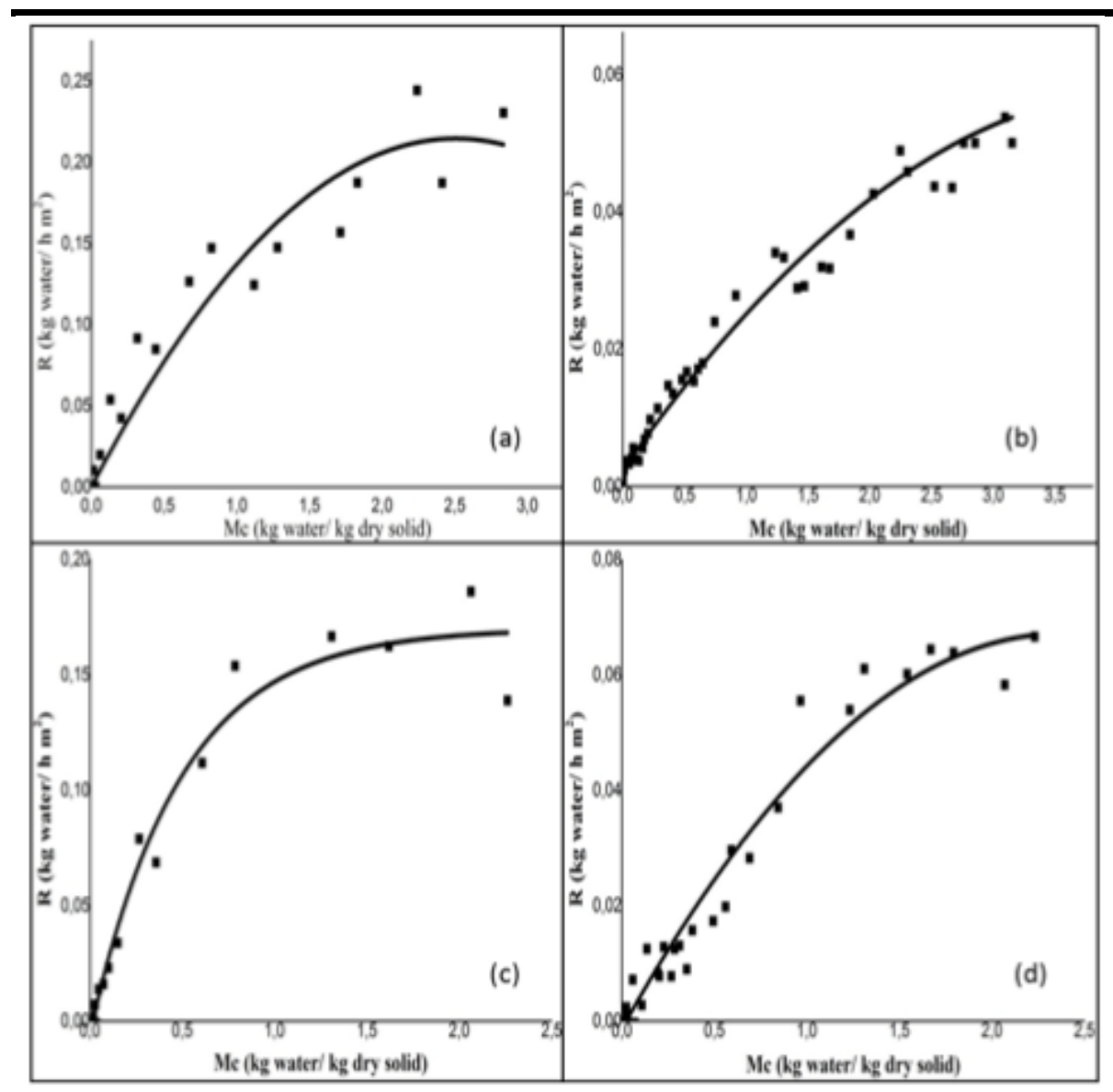

Figure 5. Drying Rate Change Over Moisture Content During Drying of Untreated Çöloğlu Apricot Species in the (a) Sunlight and (b) Shade and Sulphur Treated in the (c) Sunlight and (d) Shade 


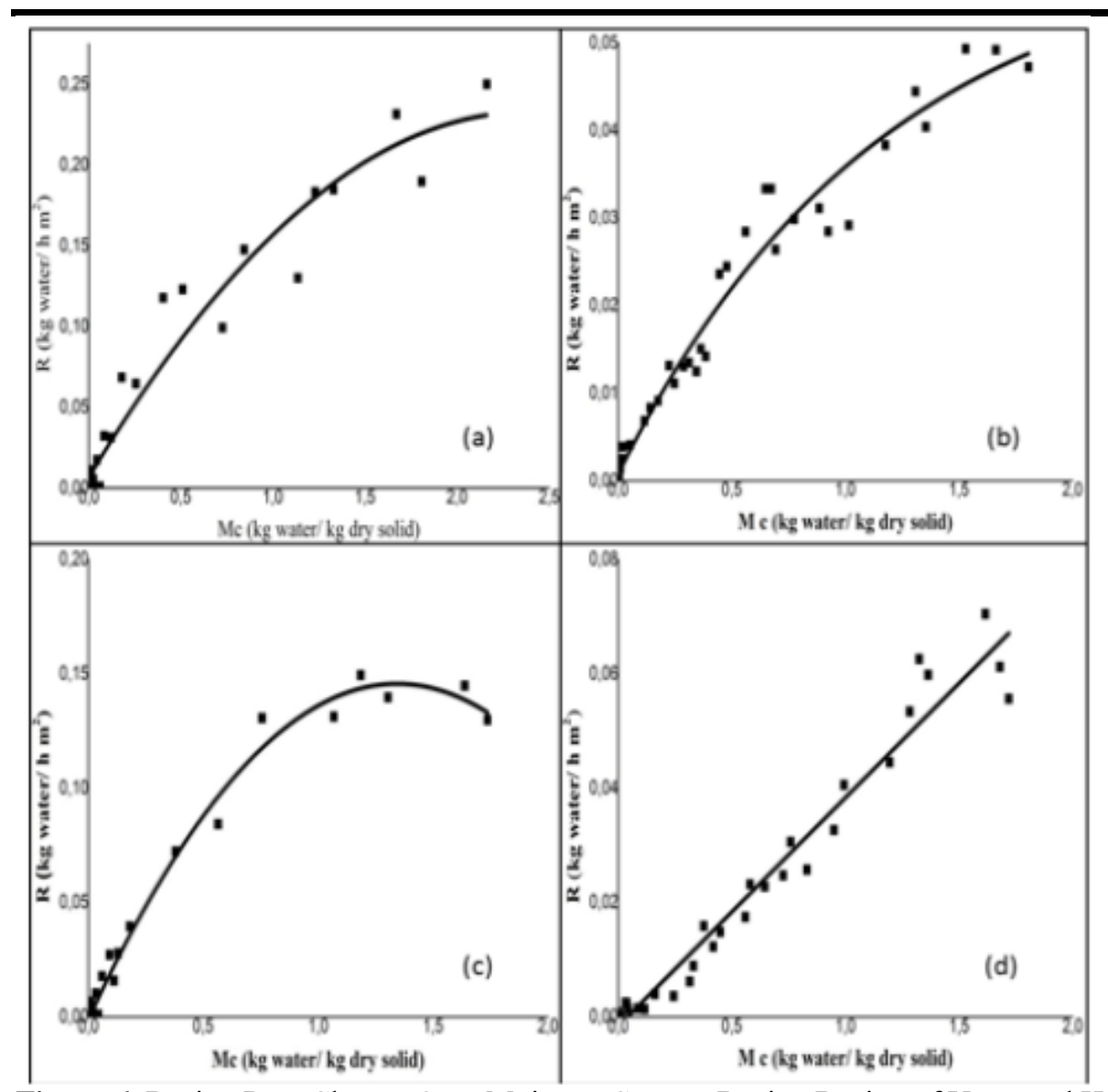

Figure 6. Drying Rate Change Over Moisture Content During Drying of Untreated Hacihaliloğlu Apricot Species in the (a) Sunlight and (b) Shade and Sulphur Treated in the (c) Sunlight and (d) Shade 


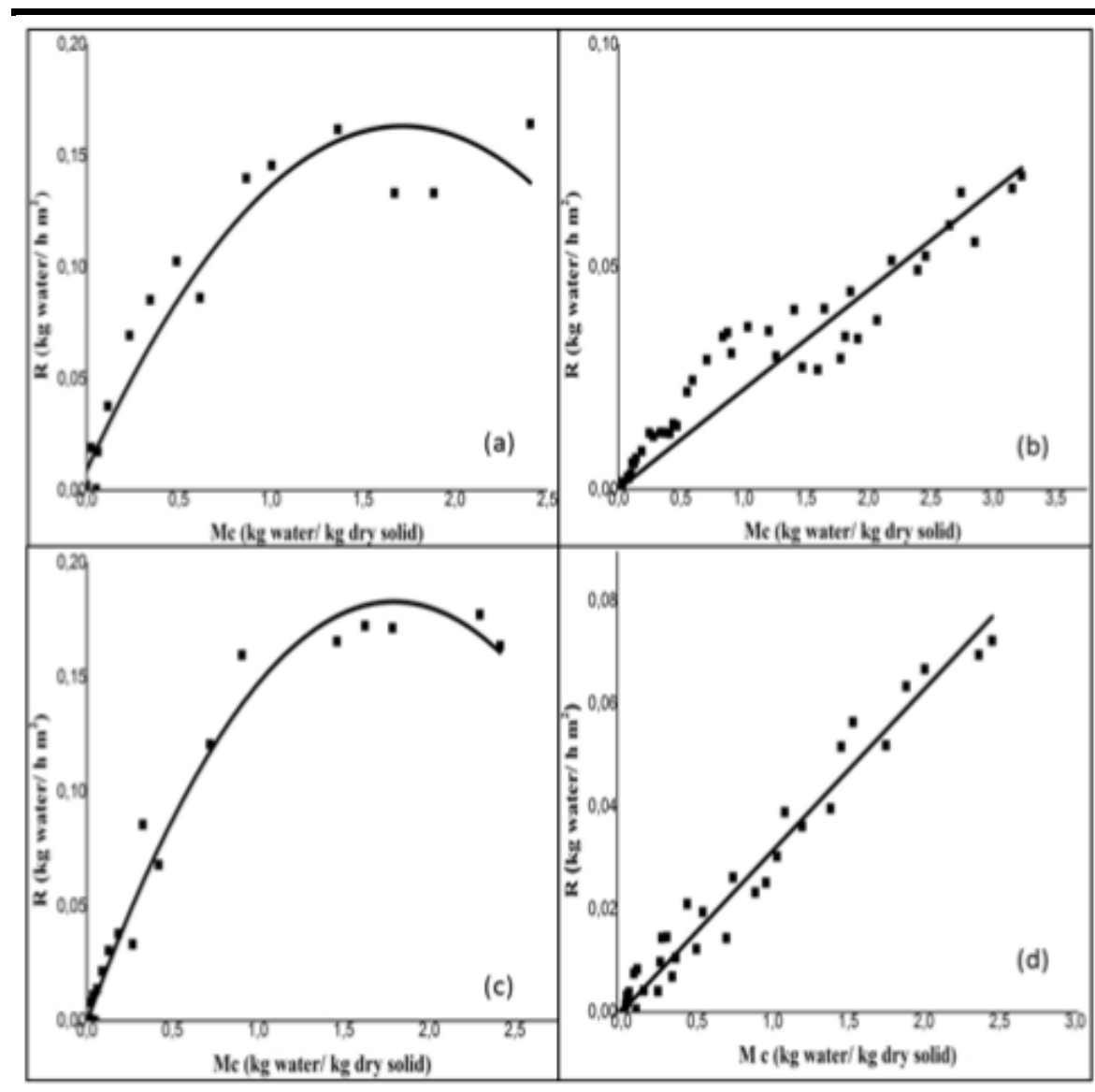

Figure 7. Drying Rate Change Over Moisture Content During Drying of Untreated Kabaaşı Apricot Species in the (a) Sunlight and (b) Shade and Sulphur Treated in the (c) Sunlight and (d) Shade 


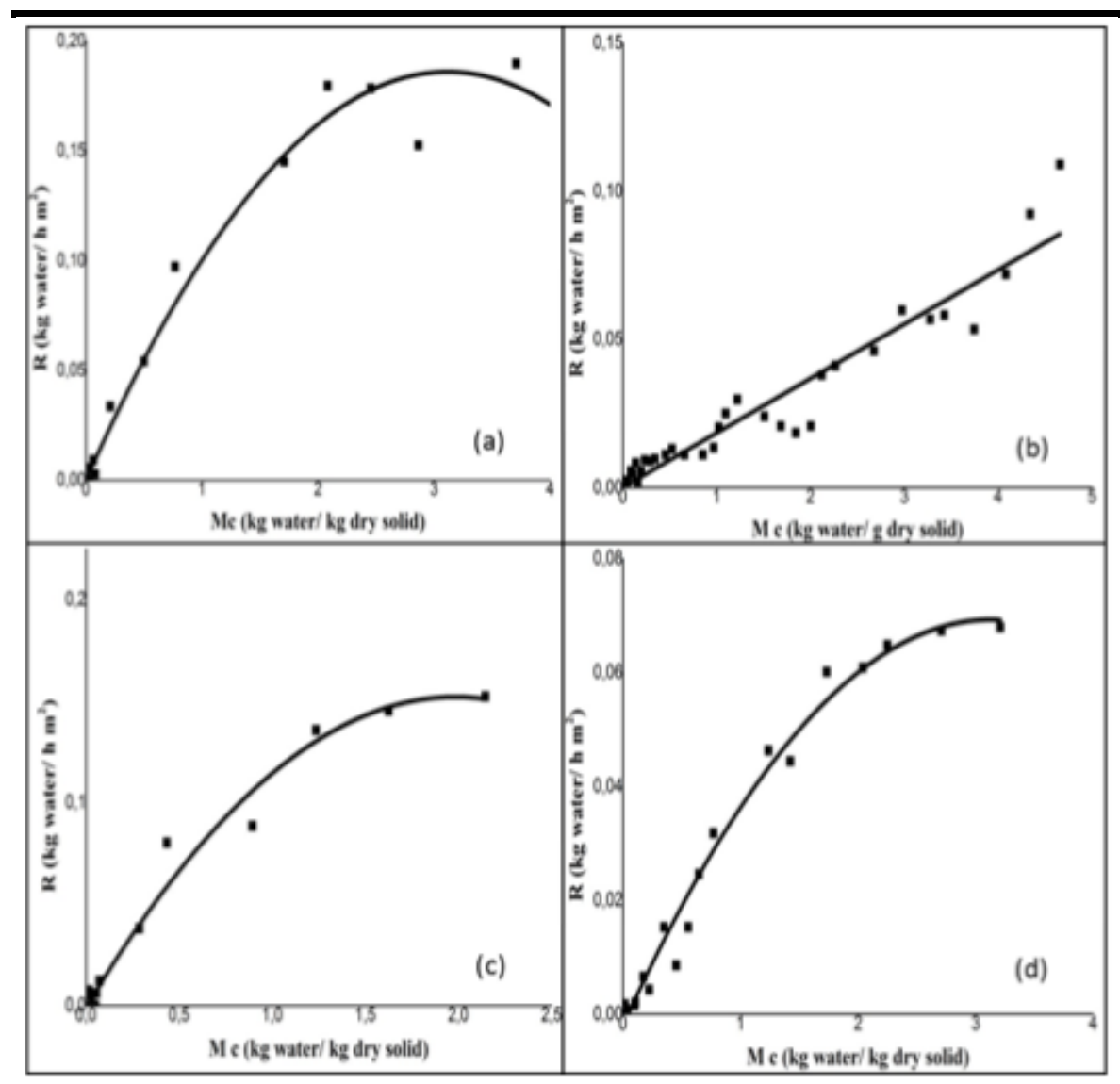

Figure 8. Drying Rate Change Over Moisture Content During Drying of Untreated Karacabey Apricot Species in the (a) Sunlight and (b) Shade and Sulphur Treated in the (c) Sunlight and (d) Shade

When these figures were evaluated for moisture content, different curves were obtained for all samples depending on the process drying environment. The drying rate curves obtained in the process of drying in the shade are closer to the linear.

Model constants and comparison criteria for unprocessed and processed species dried in sunlight are given in Table 2. The drying values in the shadow are given in Table 3.

Table 2. Modeling of Moisture Ratio of Sun Dried Apricot

\begin{tabular}{|c|c|c|c|c|c|c|c|c|c|}
\hline \multirow[b]{2}{*}{ Model } & \multirow[b]{2}{*}{ Parameters } & \multicolumn{4}{|c|}{ Untreated Species } & \multicolumn{4}{|c|}{ Treated Species } \\
\hline & & Çöloğlu & $\begin{array}{l}\text { Hacihaliloğl } \\
\mathrm{u}\end{array}$ & $\begin{array}{l}\text { Kabaaş } \\
1\end{array}$ & $\begin{array}{l}\text { Karacabe } \\
\mathrm{y}\end{array}$ & Çöloğlu & $\begin{array}{l}\text { Hacıhali } \\
\text { loğlu }\end{array}$ & Kabaaşı & $\begin{array}{l}\text { Karacabe } \\
\mathrm{y}\end{array}$ \\
\hline \multirow{5}{*}{ Page } & $\mathrm{k}$ & 0,0036 & 0,0046 & 0,0038 & 0,0577 & 0,0067 & 0,0091 & 0,0073 & 0,0523 \\
\hline & $\mathrm{N}$ & 1,319 & 1,295 & 1,2785 & 0,9016 & 1,3248 & 1,2214 & 1,2962 & 1,0138 \\
\hline & MAPE & 21,3444 & 19,6509 & 18,452 & 41,0476 & 24,8783 & 18,1922 & 20,513 & 84,4155 \\
\hline & RMSE & 0,0355 & 0,0301 & 0,0358 & 0,0473 & 0,029 & 0,0291 & 0,0277 & 0,0374 \\
\hline & $\mathrm{R}^{2}$ & 0,9955 & 0,9968 & 0,9951 & 0,9876 & 0,9965 & 0,9963 & 0,9968 & 0,9923 \\
\hline \multirow{4}{*}{ Newton } & $\mathrm{k}$ & 0,0143 & 0,0157 & 0,0128 & 0,0412 & 0,0236 & 0,218 & 0,0231 & 0,0546 \\
\hline & MAPE & 27,9358 & 28,2393 & 22,902 & 34,7421 & 36,4682 & 30,5043 & 34,599 & 72,8882 \\
\hline & RMSE & 0,0589 & 0,0529 & 0,0552 & 0,0495 & 0,0505 & 0,0425 & 0,0476 & 0,0375 \\
\hline & $\mathrm{R}^{2}$ & 0,991 & 0,993 & 0,9911 & 0,9879 & 0,9924 & 0,994 & 0,9966 & 0,9922 \\
\hline \multirow{4}{*}{$\begin{array}{l}\text { Modified } \\
\text { Handerson } \\
\text { and pabis }\end{array}$} & $\mathrm{a}$ & 0,1627 & 0,1581 & 0 & 0,1997 & 0 & 0 & 0 & 0,281 \\
\hline & b & 0,2449 & 0,2478 & 0,1861 & 0,2512 & 0,1898 & 0,1642 & 0,1654 & 0,2258 \\
\hline & $\mathrm{C}$ & 0,6388 & 0,6391 & 0,8525 & 0,4677 & 0,8664 & 0,8725 & 0,8881 & 0,4853 \\
\hline & g & 0,0151 & 0,0165 & 0,0135 & 0,0376 & 0,0249 & 0,0227 & 0,0243 & 0,0541 \\
\hline
\end{tabular}




\begin{tabular}{llllllllll}
\hline & $\mathrm{h}$ & 0,0151 & 0,0165 & 0,0135 & 0,0376 & 0,0249 & 0,0227 & 0,0243 & 0,0541 \\
& $\mathrm{k}$ & 0,0151 & 0,0165 & 0,2674 & 0,0376 & 0,4991 & 0,3613 & 0,3234 & 0,0541 \\
& $\mathrm{MAPE}$ & 27,1679 & 27,2918 & 22,416 & 38,826 & 34,3272 & 29,2207 & 32,476 & 69,7459 \\
& $\mathrm{RMSE}$ & 0,0552 & 0,0492 & 0,0523 & 0,0421 & 0,0465 & 0,0404 & 0,0438 & 0,0374 \\
& $\mathrm{R}$ & 0,9893 & 0,9917 & 0,9896 & 0,9898 & 0,9915 & 0,9934 & 0,9925 & 0,9923 \\
\hline & $\mathrm{a}$ & 0 & 0 & 0 & 0,1135 & 0 & 0 & 0 & 0,4704 \\
Approxim & $\mathrm{b}$ & 0,0934 & 0,1137 & 0,0785 & 0,0046 & 0,3276 & 0,1763 & 0,3229 & 1 \\
ation of & $\mathrm{k}$ & 0,1532 & 0,1382 & 0,1637 & 7,7943 & 0,0719 & 0,1239 & 0,0714 & 0,0546 \\
diffusion & $\mathrm{MAPE}$ & 27,9358 & 28,2393 & 22,902 & 39,741 & 36,4682 & 30,5043 & 34,599 & 72,8881 \\
& $\mathrm{RMSE}$ & 0,0589 & 0,0529 & 0,0552 & 0,0387 & 0,0505 & 0,0425 & 0,0476 & 0,0375 \\
& $\mathrm{R}$ & 0,991 & 0,993 & 0,9911 & 0,9917 & 0,9924 & 0,994 & 0,9933 & 0,9922 \\
\hline & $\mathrm{a}$ & 0,9506 & 0,9553 & 0,9514 & 0,8817 & 0,9635 & 0,9619 & 0,9666 & 0,9755 \\
& $\mathrm{~b}$ & 0 & 0 & 0 & 0 & $2,00 \mathrm{E}-05$ & 0 & $9,29 \mathrm{E}-06$ & $1,89 \mathrm{E}-06$ \\
Midilli & $\mathrm{k}$ & 0,0018 & 0,0025 & 0,0019 & 0,0223 & 0,0044 & 0,0062 & 0,0051 & 0,0443 \\
et.al. & $\mathrm{N}$ & 1,468 & 1,4218 & 1,4222 & 1,1371 & 1,4228 & 1,3058 & 1,3795 & 1,0588 \\
& $\mathrm{MAPE}$ & 19,1544 & 16,7611 & 17,087 & 31,4822 & 20,6478 & 17,2666 & 20,752 & 89,6523 \\
& $\mathrm{RMSE}$ & 0,0306 & 0,0256 & 0,031 & 0,0409 & 0,0271 & 0,027 & 0,0259 & 0,0371 \\
& $\mathrm{R}$ & 0,9964 & 0,9975 & 0,9961 & 0,9901 & 0,9968 & 0,9967 & 0,9971 & 0,9924 \\
\hline
\end{tabular}

Table 3. Modeling of Moisture Ratio of Shade Dried Apricot

\begin{tabular}{|c|c|c|c|c|c|c|c|c|c|}
\hline \multirow[b]{2}{*}{ Model } & \multirow[b]{2}{*}{$\begin{array}{l}\text { Parameter } \\
\text { s }\end{array}$} & \multicolumn{4}{|c|}{ Untreated Species } & \multicolumn{4}{|c|}{ Treated Species } \\
\hline & & Çöloğlu & $\begin{array}{l}\text { Hacihaliloğ } 1 \\
\mathrm{u}\end{array}$ & $\begin{array}{l}\text { Kabaa } \\
\text { Ş1 }\end{array}$ & $\begin{array}{l}\text { Karacab } \\
\text { ey }\end{array}$ & Çöloğlu & $\begin{array}{l}\text { Hacihaliloğ } 1 \\
\mathrm{u}\end{array}$ & $\begin{array}{l}\text { Kabaa } \\
\text { ş1 }\end{array}$ & $\begin{array}{l}\text { Karacabe } \\
\mathrm{y}\end{array}$ \\
\hline \multirow{5}{*}{ Page } & $\mathrm{k}$ & 0,0022 & 0,003 & 0,0041 & 0,0361 & 0,0081 & 0,0096 & 0,0066 & 0,0328 \\
\hline & $\mathrm{N}$ & 1,1682 & 1,1294 & 1,0858 & 0,8301 & 1,1067 & 1,0271 & 1,1261 & 1,0259 \\
\hline & MAPE & 26,678 & 27,2993 & 29,250 & 29,1823 & 9,4253 & 17,7424 & 20,21 & 33,8336 \\
\hline & RMSE & 0,0279 & 0,0237 & 0,0244 & 0,0179 & 0,009 & 0,0105 & 0,0114 & 0,0098 \\
\hline & $\mathrm{R}^{2}$ & 0,9968 & 0,9977 & 0,9974 & 0,998 & 0,9996 & 0,9995 & 0,9994 & 0,9994 \\
\hline \multirow{4}{*}{ Newton } & $\mathrm{k}$ & 0,0054 & 0,0058 & 0,0064 & 0,0176 & 0,013 & 0,0108 & 0,0117 & 0,0358 \\
\hline & MAPE & 31,476 & 31,3285 & 31,726 & 19,3125 & 21,8598 & 19,4447 & 30,502 & 25,5042 \\
\hline & RMSE & 0,0381 & 0,0311 & 0,0279 & 0,0319 & 0,0178 & 0,0114 & 0,0213 & 0,0103 \\
\hline & $\mathrm{R}^{2}$ & 0,995 & 0,9968 & 0,997 & 0,9966 & 0,9991 & 0,9995 & 0,9988 & 0,9994 \\
\hline \multirow{9}{*}{$\begin{array}{l}\text { Modified } \\
\text { Handerson } \\
\text { and Pabis }\end{array}$} & $\mathrm{a}$ & 0 & 0 & 0 & 0,1275 & 0 & 0 & 0 & 0,2387 \\
\hline & b & 0,1715 & 0,1701 & 0,2317 & 0 & 0,0906 & 0,184 & 0 & 0,1548 \\
\hline & C & 0,8486 & 0,8444 & 0,7686 & 0,8592 & 0,9362 & 0,8169 & 1,0286 & 0,6165 \\
\hline & g & 0,0056 & 0,0059 & 0,0064 & 0,0376 & 0,0134 & 0,0109 & 0,0308 & 0,0362 \\
\hline & $\mathrm{h}$ & 0,0056 & 0,0059 & 0,0064 & 0,0148 & 0,0134 & 0,0109 & 0,0121 & 0,0362 \\
\hline & $\mathrm{k}$ & 0,148 & 0,1639 & 0,1161 & 0,3192 & 0,156 & 0,1328 & 0,0906 & 0,0362 \\
\hline & MAPE & 31,173 & 38,6103 & 31,722 & 20,8941 & 19,7977 & 19,4087 & 29,023 & 26,7767 \\
\hline & RMSE & 0,0374 & 0,062 & 0,0279 & 0,0105 & 0,0157 & 0,0114 & 0,0193 & 0,0099 \\
\hline & $\mathrm{R}^{2}$ & 0,9946 & 0,9988 & 0,997 & 0,9993 & 0,9989 & 0,9995 & 0,9985 & 0,9994 \\
\hline \multirow{6}{*}{$\begin{array}{l}\text { Approximat } \\
\text { ion of } \\
\text { diffusion }\end{array}$} & $\mathrm{a}$ & 0 & 0 & 0 & 0,1366 & 0 & 0 & 0 & 0 \\
\hline & b & 0,1365 & 0,1731 & 0,1375 & 0,0347 & 0,0843 & 0,069 & 0,0747 & 0,3914 \\
\hline & $\mathrm{k}$ & 0,0398 & 0,0337 & 0,0468 & 0,4282 & 0,1546 & 0,1572 & 0,1565 & 0,0916 \\
\hline & MAPE & 31,476 & 31,3285 & 31,726 & 20,5451 & 21,8598 & 19,4448 & 30,502 & 25,5042 \\
\hline & RMSE & 0,0381 & 0,0311 & 0,0279 & 0,0107 & 0,0178 & 0,0114 & 0,0213 & 0,0103 \\
\hline & $\mathrm{R}^{2}$ & 0,9952 & 0,9968 & 0,997 & 0,9992 & 0,9991 & 0,9995 & 0,9988 & 0,9994 \\
\hline \multirow{7}{*}{$\begin{array}{l}\text { Midilli } \\
\text { et.al. }\end{array}$} & $\mathrm{a}$ & 0,9272 & 0,9383 & 0,9345 & 0,9455 & 0,9852 & 0,9816 & 0,9755 & 1,0035 \\
\hline & b & 0 & 0 & 0 & 0 & 0 & 0 & 0 & 2,11E-05 \\
\hline & $\mathrm{k}$ & 8,00E-04 & 0,0014 & 0,0019 & 0,0257 & 0,0071 & 0,0082 & 0,0052 & 0,0328 \\
\hline & $\mathrm{N}$ & 1,3415 & 1,2618 & 1,2194 & 0,8962 & 1,1328 & 1,0565 & 1,1721 & 1,0276 \\
\hline & MAPE & 23,055 & 24,4837 & 26,562 & 25,919 & 7,8832 & 16,659 & 17,545 & 17,4248 \\
\hline & RMSE & 0,0203 & 0,0179 & 0,0187 & 0,0149 & 0,0083 & 0,0097 & 0,01 & 0,0096 \\
\hline & $\mathrm{R}^{2}$ & 0,9982 & 0,9986 & 0,9984 & 0,9985 & 0,9996 & 0,9995 & 0,9995 & 0,9995 \\
\hline
\end{tabular}


The results show that the values of $\mathrm{R}^{2}$ ranged from 0.9876 to 0.9975 for under sun drying and 0,9946 to 0,9996 for shade drying. It can be seen from Table 2 and 3 that the highest $\mathrm{R}^{2}$ values were observed with Midilli et al. and Page models. But Midilli et al. model presents lower MAPE and RMSE compared to the Page model. Therefore, the Midilli et al. model could be selected to describe the drying behavior of apricots (Midilli et al., 2002).

The performance of the Midilli et al. model is illustrated in Fig. 9.

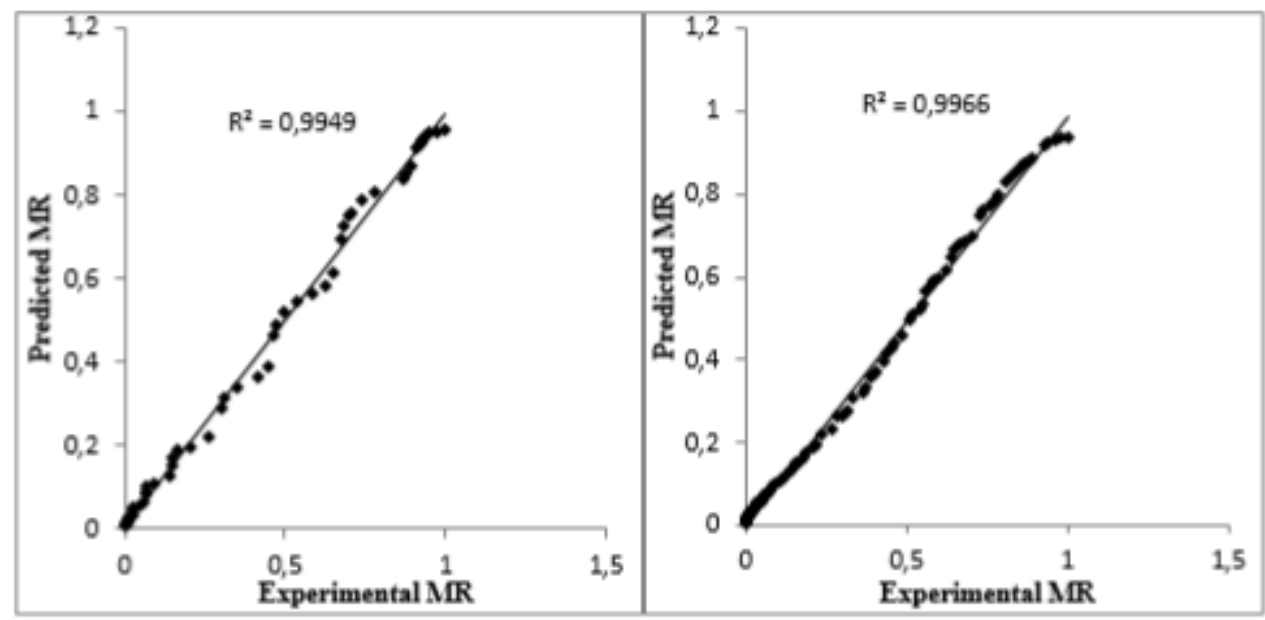

Figure 9. Experimental and Predicted Moisture Contents of Untreated Hacıhaliloğlu Species for Midilli et al. Model in the (a) Sunlight and (b) Shade

The study, applied to models and dried in the sun it has been determined that apricots generally fit the pony model. From current studies in which there are drying mechanisms of various apricot species with different biological properties in different drying environments, the following results have been reached.

The removal of water from selected apricot species in the drying process was measured as approximately $1.75-4.5 \mathrm{~kg}$ of water per $\mathrm{kg}$ of dry matter for apricots treated with sulfur from the initial moisture content. For unprocessed apricots, there was a reduction in the final moisture content of 2.25-5.0 kg of water per kg of dry matter, it was found that the maximum amount of water can be removed in the shortest time possible in the Karacabey species. According to the results of the SQP analysis, among the five different models, the Midilli et al. model described best the drying behavior of apricots (within 99.9\%).

\section{RESULT}

In the evaluation of experimental results of drying different types of apricots in different drying environments as sun, shade and oven, the free moisture-time curves of all samples showed similar changes. But the time of apricots to reach the equilibrium moisture value is different. Because the size and structure of apricots is different in the ratio of water. The time 
to reach the equilibrium moisture value is different due to differences in the size, type and water ratio of apricots. Heat transfer rate and mass transfer rate are important in the drying process. In the study, Karacabey apricots have been determined to have low carbohydrate content and high moisture content, while Hacihaliloğlu species have high carbohydrate and low moisture content. Drying rates increased in the range of $0.150-0.225 \mathrm{~kg}$ of water/ hour $\mathrm{m}^{2}$ when drying sulfur and sulfur-free species in the sun. In shade drying, these values were obtained in the range of $0.049-0.080 \mathrm{~kg}$ of water/ hour $\mathrm{m}^{2}$. According to the results of multiple linear regression analyses, among the five (5) models, the pony model corresponds to dry all apricots with and without sulfur. The Gel. Henderson Pabis model fits the drying of apricots divided into two parts (splitting).

\section{Acknowledgements}

The author would like to thank Scientific Research Project Unit of İnönü University for their financial support Project Number: 2012-184.

\section{REFERENCES}

Akpınar Kavak, E., Biçer, Y., Midilli, A. (2003). Modelling and experimental study on drying of apple slices in a convective cyclone dryer. Journal of Food Process Engineering, 26 (6), 515-541.

Akpınar Kavak, E., Biçer, Y., Yıldız, C. (2003). Thin layer drying of red pepper. Journal of Food Engineering, 59 (1), 99-104.

Bozkır, O. (2006). Thin-layer drying and mathematical modelling for washed dry apricots. Journal of Food Engineering, 77 (1), 146-151.

Diamante, L. M., Munro, P. A. (1991). Mathematical modelling of hot air drying of sweet potato slices. International Journal of Food Science \& Technology, 26 (1), 99-109.

Glen, E. (1949). Factors influencing the maximum rates of air-drying shelled corn in thin layers. Lafayette. (M.S. Thesis). Purdue University, ABD.

Krokida, M. K. Karathanos, V. T., Maroulis, Z. B., Marinos-Kouris, D. (2003). Drying kinetics of some vegetables. Journal of Food Engineering, 59 (4), 391-403.

Midilli, A., Kücük, H., Yapar, Z. (2002). A new model for single-layer drying. Drying Technology, 20 (7), $1503-$ 1513.

O’Callaghan, J. R., Menzies, D. J., Bailey, P. H. (1971). Digital simulation of agricultural drier performance. Journal of Agricultural Engineering Research, 16 (3), 223-244.

Pala, M., Mahmutoglu, T., Saygi, B. (1996). Effects of pretreatments on the quality of open-air and solar dried products. Food, 40, 137-141.

Sarsavadiya, P. N., Sawhney, R. L., Pangavhane, D. R., Singh, S. P. (1999). Drying behaviour of brined onion slices. Journal of Food Engineering, 40, 219-226.

Sawhney, R. L., Pangavhane, D. R., Singh, S. P. (1999). Drying behaviour of brined onion slices. Journal of Food Engineering, 40 (3), 219-226. 
Sharaf-Eldeen, Y. I., Hamdy, M. Y., Keener, H. M., Blaisdell, J. L. (1979). Mathematical description of drying fully exposed grains. American Society of Agricultural Engineers, 31, 79-3034.

Sharma, G. P., Verma, R. C., Pankaj, P. (2005). Mathematical modeling of infrared radiation thin layer drying of onion slices. Journal of Food Engineering, 71 (3), 282-286.

Toğrul-Türk, I., Toğrul, H. (2007). Determination of moisture transport parameters of some fruits under open sun drying conditions. International Journal of Green Energy, 4 (4), 397-408.

Yaldız, O., Ertekin, C. (2001). Thin layer solar drying of some vegetables. Drying Technology, 19 (3-4), 583-597. 